\title{
Review \\ Does Probiotic Consumption Enhance Wound Healing? A Systematic Review
}

\author{
Camille Togo ${ }^{1, * \mathbb{D}}$, Ana Paula Zidorio ${ }^{1,2}$, Vivian Gonçalves ${ }^{3} \mathbb{D}$, Patrícia Botelho ${ }^{1} \mathbb{D}$, Kenia de Carvalho ${ }^{1}$ and \\ Eliane Dutra ${ }^{1}$
}

check for updates

Citation: Togo, C.; Zidorio, A.P.; Gonçalves, V.; Botelho, P.; de Carvalho, K.; Dutra, E. Does Probiotic Consumption Enhance Wound Healing? A Systematic Review. Nutrients 2022, 14, 111 https://doi.org/10.3390/ nu14010111

Academic Editor: Anja Saalbach

Received: 22 October 2021

Accepted: 23 December 2021

Published: 27 December 2021

Publisher's Note: MDPI stays neutral with regard to jurisdictional claims in published maps and institutional affiliations.

Copyright: (C) 2021 by the authors. Licensee MDPI, Basel, Switzerland. This article is an open access article distributed under the terms and conditions of the Creative Commons Attribution (CC BY) license (https:// creativecommons.org/licenses/by/ $4.0 /)$.
1 Graduate Program in Human Nutrition, Faculty of Health Sciences, University of Brasilia, Campus Universitario Darcy Ribeiro, Brasilia 70910-900, Brazil; anacaio@unb.br (A.P.Z.); patriciabotelho@unb.br (P.B.); kenia@unb.br (K.d.C.); elidutra@unb.br (E.D.)

2 Clinical Nutrition Unit, University Hospital of Brasilia, Brasilia 70840-901, Brazil

3 Graduate Program in Public Health, Faculty of Health Sciences, University of Brasilia, Campus Universitario Darcy Ribeiro, Brasilia 70910-900, Brazil; vivian.goncalves@unb.br

* Correspondence: camillecristogo@gmail.com

\begin{abstract}
The use of probiotics is one of the emerging lines of treatment for wound healing. This systematic review aimed to summarize currently available evidence on the effect of oral or enteral probiotic therapy on skin or oral mucosal wound healing in humans. To verify the developments in this field and the level of available scientific evidence, we applied a broad search strategy with no restrictions on wound type, target population, probiotic strain, or intervention protocol used. This review included seven studies involving 348 individuals. Four studies reported positive outcomes for healing improvement after probiotic therapy, and none of the studies reported adverse effects or a marked increase in wound healing time. The positive or neutral results observed do not generate strong evidence regarding the effectiveness of probiotics for wound healing. However, they suggest a promising field for future clinical research where the probiotic strains used, type of wounds, and target population are controlled for.
\end{abstract}

Keywords: probiotics; skin wound; oral mucosal wound; wound healing; systematic review

\section{Introduction}

Skin and mucosal wounds encompass a wide variety of injuries, including a surgical scar, pressure ulcer, extensive burn, and an open abdominal wound. Healing is an inherent process in all wounds, regardless of the cause. It is a systemic, dynamic, and expected process related to the general conditions of the organism [1], and can be negatively or positively influenced by local and systemic factors. The local factors that hinder wound healing include ischemia, infection, surgical technique, foreign body, and oedema [2], while systemic factors include vitamin deficiencies, malnutrition [3,4], and other conditions such as diabetes mellitus [5] and cardiovascular and respiratory diseases [1].

Wound care practices involve technical procedures, topical agents, and dressings, as well as holistic and systemic treatment, where the patient, and not just the wound, are observed [6]. An emerging treatment line for skin wounds and conditions is the use of probiotics, defined by the International Scientific Association of Probiotics and Prebiotics as "live microorganisms which when administered in adequate amounts confer a health benefit on the host" [7].

Probiotics have been extensively investigated, and their role in improving infections and intestinal healing is well-known [8,9]. Researchers have reported that probiotics may have other health-promoting effects beyond intestinal wellbeing [10-12], such as preventing recurrent urinary tract infections in women and reducing respiratory tract infections [13-15]. In addition, a narrative literature review reported the beneficial effects of oral administration and topical application of probiotics for the treatment of skin diseases [15]. 
Studies have been conducted in order to evaluate the use of probiotics to enhance wound healing. Yu et al. reviewed the usefulness of oral and topical probiotics for certain dermatological diseases. The authors suggested that these interventions could be effective in the treatment of certain inflammatory skin diseases, with a promising role in promoting wound healing and managing skin cancer [16]. However, the use of probiotics as a nutritional supplement to treat skin or mucosal wounds was not emphasized in their review [16]. Animal studies have demonstrated a positive effect of probiotics in reducing bacterial load and increasing tissue repair $[17,18]$. In addition, in vitro studies $[8,19]$ have demonstrated a positive effect for probiotics on the recovery of structural elements of the skin.

Although in vitro and in vivo animal studies support the potential for probiotics to promote skin healing, it is of paramount importance to investigate the level of existing evidence reported in human studies. Therefore, the aim of this systematic review was to summarize currently available evidence on the effect of oral or enteral probiotic therapy on skin or oral mucosal wound healing in humans.

\section{Materials and Methods}

\subsection{Protocol and Registration}

This systematic review followed the Preferred Reporting Items for Systematic Reviews and Meta-Analyses (PRISMA) checklist [20] and the protocol was registered in the International Prospective Register of Systematic Reviews (PROSPERO) under the registration number CRD42020150682.

\subsection{Eligibility Criteria}

Randomised and non-randomised placebo-controlled trials that recruited people of all age groups and both sexes, with skin or oral mucosal wounds, receiving oral or enteral probiotic therapy with or without antibiotic treatment, and with healing assessment data, were included. Given that the preliminary searches identified few studies when limited to the type of wound, probiotic, or target population, we applied a broad search strategy to verify the scientific evidence level and evaluate the developments in this field. Reviews, congress abstracts, chapters of books, meeting proceedings, and studies without clear outcomes were not included. Furthermore, animal studies, in vitro studies, and studies with topical use of probiotics were excluded. There were no restrictions on the date, language, or publication status.

\subsection{Information Sources and Search Strategies}

The search strategy was developed based on the criteria recommended by the Peer Review of Electronic Search Strategies (PRESS) checklist [21] and submitted for revision by a researcher experienced in conducting systematic reviews. Detailed search strategies with adaptations of descriptors and term combinations were elaborated on according to the specificities of the following databases: Medline (through PubMed), Embase, Lilacs, Scopus, and Web of Science. A partial grey literature search was also conducted using the ProQuest database of theses and dissertations and Google Scholar, wherein the search was limited to the first 200 articles found. Finally, a search was performed of the clinical trials record database ClinicalTrials.gov (Table S1).

Rayyan QCRI software (Qatar Computing Research Institute ${ }^{\circledR}$, Doha, Qatar) [22] was used to remove duplicates and facilitate screening of the identified records. All references were managed using Mendeley Desktop software (Version 1.19.8; Mendeley Ltd., London, UK).

\subsection{Study Selection}

The study selection process was conducted in two phases by two independent researchers. In phase one, articles were selected according to their titles and abstracts based on the inclusion criteria. Any disagreements were resolved by consensus. In phase two, the 
selected articles were read in their entirety, and those that met the inclusion criteria were included. A manual search of the reference lists of the selected articles was also performed.

\subsection{Data Collection Process}

Data extraction was also performed independently by two authors. Any disagreements were resolved by consensus. The following data were extracted from the selected articles and recorded in an electronic spreadsheet: country, aim and study design, subjects/patients, type of wounds, intervention protocol, healing assessments, outcome of interest, possible adverse effects of probiotic therapy, and whether probiotic therapy improved wound healing.

\subsection{Risk of Bias in Individual Studies}

The critical appraisal tools recommended by the Joanna Briggs Institute [23] for randomised controlled trials and quasi-experimental studies (non-randomised experimental studies) were used to assess the risk of bias of the included studies. Two reviewers independently evaluated each study, and a third reviewer resolved disagreements. Both tools have the answers 'yes', 'no', 'unclear', or 'not applicable' for the questions. For this review, when all answers were 'yes', the study was classified as having a low risk of bias, and if any answer was 'no' or 'unclear', the study was classified as having a risk of bias. No scores were assigned; the results for each question were expressed as the frequency of each classification. In the cases where information was not clear, at least two attempts were made to request additional information from the authors. Evaluation of the risk of bias was not used as a part of the eligibility criteria for article inclusion.

\subsection{Synthesis of Results}

The primary outcome investigated was wound healing after probiotic therapy, and the secondary outcome was the safety of probiotic consumption. To assess the primary outcome, the methods of healing assessments used in each eligible study were examined. The quantitative or qualitative methods used to evaluate the outcome were identified. For the assessment of the secondary outcome, the reported adverse effects in the studies were considered.

\section{Results}

\subsection{Study Selection}

In the initial search performed using the selected databases, 6268 publications were identified. After the removal of duplicates, the titles and abstracts of 3751 publications were assessed, and 22 studies were selected for full-text reading. From a manual search of the reference lists of the articles, eight more articles were selected for the full-text reading. Finally, seven studies met the eligibility criteria (Figure 1). The reasons for the exclusion of articles are described in Table S2.

\subsection{Study Characteristics}

Table 1 presents the characteristics, objectives, intervention protocols, and main outcomes of the seven studies included in this review [24-30]. The studies were published between 2014 [24] and 2019 [25], and were carried out in Egypt [26], Italy [27], the United States [28], Iran [29], Pakistan [24], Denmark [30], and Sweden [25]. Three studies assessed the effect of oral/enteral probiotic therapy on burn healing [24,26,28]. El-Ghazely et al., Tahir et al. and Mayes et al. assessed aspects related to skin grafting [24,26,28]. Six studies were randomised clinical trials [25-30], and one conducted by Tahir et al. was a placebocontrolled, non-randomised clinical trial [24]. The seven studies included in this review enrolled a total of 348 subjects of both sexes ( 225 males). The age range was 11 months to 85 years. 


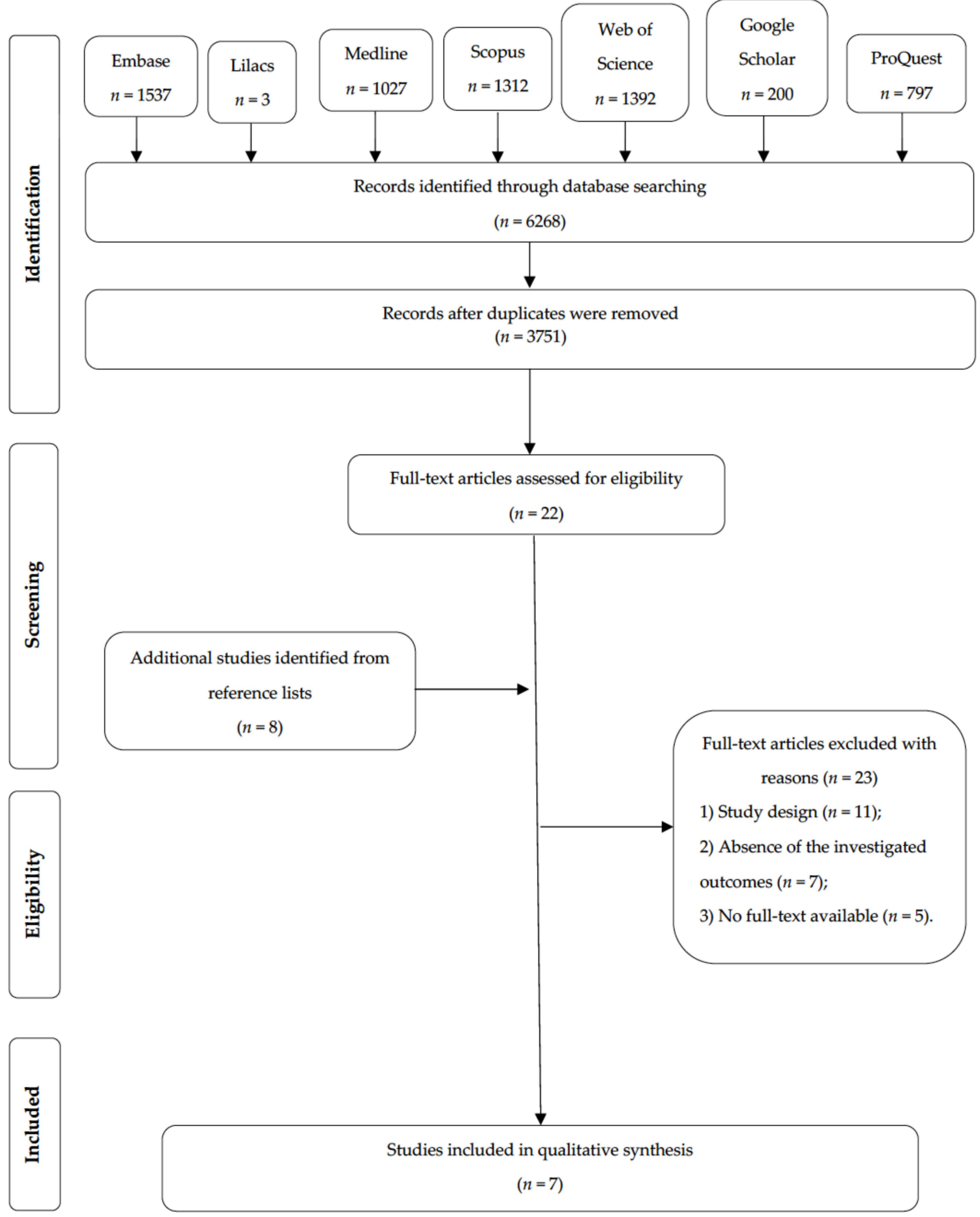

Figure 1. Flow diagram of the literature search and selection criteria. 
Table 1. Summary of the characteristics and outcomes of the included studies.

\begin{tabular}{|c|c|c|c|c|c|c|c|}
\hline Study (Country) & Aim of the Study & $\begin{array}{c}\text { Study } \\
\text { Design }\end{array}$ & $\begin{array}{l}\text { Subjects/ } \\
\text { Patients }\end{array}$ & Type of Wounds & Intervention Protocol & $\begin{array}{c}\text { Healing } \\
\text { Assessments }\end{array}$ & Outcome of Interest \\
\hline $\begin{array}{l}\text { El-Ghazely et al. } 2016 \\
\text { (Egypt) [26] }\end{array}$ & $\begin{array}{l}\text { To evaluate the effect of } \\
\text { oral probiotic therapy on } \\
\text { the outcome of paediatric } \\
\text { patients }\end{array}$ & $\begin{array}{l}\text { Prospective, randomised, } \\
\text { double-blind, } \\
\text { placebo-controlled clinical } \\
\text { trial }\end{array}$ & $\begin{array}{l}\text { Total: } 40 \\
\text { Group } 1 \text { (probiotic): } 20 \\
\text { (14 males) } \\
\text { Group 2 (control): } 20 \\
\text { (12 males) } \\
\text { Age: } 1-14 \text { years }\end{array}$ & Thermal burn & $\begin{array}{l}\text { Probiotics: Lactobacillus } \\
\text { fermentum and Lactobacillus } \\
\text { delbruekii } \\
\text { Dosage: } 10 \text { billion } \\
\text { colony-forming units } \\
\text { (CFU)/sachet } \\
\text { Administration: sachets } \\
\text { Frequency: } 2 \text { times/day } \\
\text { Placebo group: starch } \\
\text { Treatment period: } 15 \text { days }\end{array}$ & Need for grafting & $\begin{array}{l}\text { Need for grafting was } \\
\text { significantly lower in the } \\
\text { probiotic group (probiotics: } 10 \% \\
\text { vs. control: } 40 \%, p=0.028) \text {. } \\
\text { Significant decrease in the time } \\
\text { needed for complete burn } \\
\text { wound healing in the probiotic } \\
\text { group was observed when the } \\
\text { graft was not performed } \\
\text { (16.25 } \pm 0.23 \text { days vs. } \\
20.7 \pm 0.51 \text { days, } p=0.048) .\end{array}$ \\
\hline $\begin{array}{l}\text { Esposito et al. } 2018 \\
\text { (Italy) [27] }\end{array}$ & $\begin{array}{l}\text { To assess the effectiveness } \\
\text { of probiotics as a } \\
\text { preventive measure for } \\
\text { antibiotic-associated } \\
\text { diarrhoea in paediatric } \\
\text { patients and its clinical } \\
\text { consequences on the } \\
\text { post-operative outcome }\end{array}$ & $\begin{array}{l}\text { Prospective, randomised, } \\
\text { placebo-controlled trial }\end{array}$ & $\begin{array}{l}\text { Total: } 90 \text { (only males) } \\
\text { Group } 1 \text { (probiotics + } \\
\text { antibiotics): } 30 \\
\text { Group } 2 \text { (antibiotics): } 30 \\
\text { Group } 3 \text { (antibiotics + } \\
\text { placebo): } 30 \\
\text { Age: } 11-36 \text { months } \\
\text { (average } 15 \text { months) }\end{array}$ & $\begin{array}{l}\text { Surgical (hypospadias } \\
\text { repair) }\end{array}$ & $\begin{array}{l}\text { Probiotics: Lactobacillus } \\
\text { rhamnosus GG (ATCC } \\
53103 \text { ) } \\
\text { Dosage: } 5 \text { drops of } 5 \times 10^{9} \\
\text { CFU } \\
\text { Administration: drops } \\
\text { Frequency: } 1 \text { time } / \text { day } \\
\text { Placebo group: drops of } \\
\text { glucose solution at } 5 \% \\
\text { Treatment period: } \\
\text { approximately } 2 \text { h after } \\
\text { administration of } \\
\text { antibiotics, for } 4-16 \text { days, } \\
\text { depending on the duration } \\
\text { of antibiotic therapy }\end{array}$ & $\begin{array}{l}\text { Number of } \\
\text { dressings } \\
\text { needed/day and } \\
\text { postoperative } \\
\text { wound } \\
\text { complications }\end{array}$ & $\begin{array}{l}\text { Frequency of dressing change } \\
\text { was significantly lower in the } \\
\text { probiotic group (average } \\
\text { number/day: G1 } 1=1.7 \text { vs. } \\
\text { G2 }=3.3 \text { vs. G3 }=2.8, p=0.001 \text { ). } \\
\text { Incidence of postoperative } \\
\text { wound complications was } \\
\text { significantly higher in the other } \\
\text { groups compared to the } \\
\text { probiotic group ( } \mathrm{G} 1=3.3 \% \text { vs. } \\
\text { G2 }=6.6 \% \text { vs. G3 }=6.6 \% \text {, } \\
p=0.001 \text { ). }\end{array}$ \\
\hline $\begin{array}{l}\text { Mayes et al. 2015 } \\
\text { (United States) [28] }\end{array}$ & $\begin{array}{l}\text { To assess the probiotic } \\
\text { provision safety in } \\
\text { paediatric patients } \\
\text { receiving enteral nutrition } \\
\text { and to provide a } \\
\text { preliminary evaluation of } \\
\text { the effect of oral probiotic } \\
\text { therapy on clinical } \\
\text { outcome }\end{array}$ & $\begin{array}{l}\text { Prospective, randomised, } \\
\text { blinded, } \\
\text { placebo-controlled trial }\end{array}$ & $\begin{array}{l}\text { Total: } 20 \\
\text { Group } 1 \text { (probiotic): } 10 \\
\text { (6 males) } \\
\text { Group 2 (placebo): } 10 \\
\text { (8 males) } \\
\text { Age: Group 1: } 7.1 \pm 2.2 \\
\text { years } \\
\text { Group 2: } 6.9 \pm 1.7 \text { years }\end{array}$ & Burn & $\begin{array}{l}\text { Probiotics: Lactobacillus } \\
\text { rhamnosus GG } \\
\text { Dosage: } 15 \text { billion } \\
\text { CFU/unit dose } \\
\text { Administration: } \\
\text { nasoduodenal feeding tube } \\
\text { Frequency: } 2 \text { times/day } \\
\text { Placebo group: } \\
\text { identical appearance, with } \\
\text { the same inactive } \\
\text { ingredient base } \\
\text { Treatment period: } \\
\text { beginning within } 10 \text { days } \\
\text { of burn and continuing } \\
\text { until } 95 \% \text { wound closure } \\
\text { was achieved }\end{array}$ & $\begin{array}{l}\text { Wound length of } \\
\text { stay (WLOS) and } \\
\text { operative days for } \\
\text { excision and graft }\end{array}$ & $\begin{array}{l}\text { A reduced healing time was not } \\
\text { observed in the probiotic group } \\
\text { (probiotic: } 0.83 \pm 0.1 \text { vs. } \\
\text { placebo: } 1.02 \pm 0.1, p<0.23 \text { ). } \\
\text { There was no difference in the } \\
\text { number of operative days for } \\
\text { excision and grafting } \\
\text { procedures (probiotic: } 2.3 \pm 0.5 \\
\text { vs. placebo: } 3.3 \pm 0.6, p<0.23 \text { ). } \\
\text { Clinical safety of oral therapy } \\
\text { with probiotics in paediatric } \\
\text { patients with burns. }\end{array}$ \\
\hline
\end{tabular}


Table 1. Cont.

\begin{tabular}{|c|c|c|c|c|c|c|c|}
\hline Study (Country) & Aim of the Study & $\begin{array}{c}\text { Study } \\
\text { Design }\end{array}$ & $\begin{array}{l}\text { Subjects/ } \\
\text { Patients }\end{array}$ & Type of Wounds & Intervention Protocol & $\begin{array}{c}\text { Healing } \\
\text { Assessments }\end{array}$ & Outcome of Interest \\
\hline $\begin{array}{l}\text { Mohseni et al. } 2018 \\
\quad \text { (Iran) [29] }\end{array}$ & $\begin{array}{l}\text { To determine the effects of } \\
\text { oral probiotic therapy on } \\
\text { wound healing and } \\
\text { metabolic status in adult } \\
\text { patients with diabetes }\end{array}$ & $\begin{array}{l}\text { Randomised, double-blind, } \\
\text { placebo-controlled trial }\end{array}$ & $\begin{array}{l}\text { Total: } 60 \\
\text { Group } 1 \text { (probiotic): } 30 \\
\text { (20 males) } \\
\text { Group } 2 \text { (placebo): } 30 \\
\text { (20 males) } \\
\text { Age: } 40-85 \text { years }\end{array}$ & Diabetic foot ulcer & $\begin{array}{l}\text { Probiotics: Lactobacillus } \\
\text { acidophilus, Lactobacillus } \\
\text { casei, Lactobacillus } \\
\text { fermentum, and } \\
\text { Bifidobacterium bifidum } \\
\text { Dosage: } 2 \times 10^{9} \mathrm{CFU} / \mathrm{g} \\
\text { Administration: capsule } \\
\text { Frequency: daily } \\
\text { Placebo group: not } \\
\text { informed } \\
\text { Treatment period: } 12 \\
\text { weeks }\end{array}$ & $\begin{array}{l}\text { Mean ulcer area and } \\
\text { ulcer volume }\end{array}$ & $\begin{array}{l}\text { Significant improvement in } \\
\text { parameters of wound healing in the } \\
\text { probiotic group } \\
\text { (ulcer length: } \\
-1.3 \pm 0.9 \text { vs. }-0.8 \pm 0.7 \mathrm{~cm}, p=0.01 \text {; } \\
\text { width: } \\
-1.1 \pm 0.7 \text { vs. }-0.7 \pm 0.7 \mathrm{~cm}, p=0.02 \text {; } \\
\text { depth: } \\
-0.5 \pm 0.3 \text { vs. } \\
-0.3 \pm 0.3 \mathrm{~cm}, p=0.02) \text {. }\end{array}$ \\
\hline $\begin{array}{l}\text { Tahir et al. 2014 } \\
\text { (Pakistan) [24] }\end{array}$ & $\begin{array}{l}\text { To find an alternate, } \\
\text { effective method to reduce } \\
\text { infection, predict graft take, } \\
\text { and minimise hospital stay } \\
\text { in adult patients }\end{array}$ & $\begin{array}{l}\text { Prospective, } \\
\text { placebo-controlled trial, } \\
\text { not randomised }\end{array}$ & $\begin{array}{l}\text { Total: } 64 \\
\text { Group } 1 \text { (probiotic): } 22 \\
\text { (10 males) } \\
\text { Group 2 (control): } 42 \\
\text { (12 males) } \\
\text { Age: Group 1: } 28.2 \pm 10.2 \\
\text { years } \\
\text { Group 2: } 30.2 \pm 13.80 \text { years }\end{array}$ & Burn & $\begin{array}{l}\text { Probiotics: Lactobacillus } \\
\text { acidophilus LA-5, } \\
\text { Bifidobacterium BB-12, } \\
\text { Streptococcus thermophilus } \\
\text { STY-31, and } \\
\text { Lactobacillus delbrueckii ssp. } \\
\text { bulgaricus LBY-27 } \\
\text { Dosage: } 2 \mathrm{~g} \text { of }>8 \text { billion } \\
\text { CFU/sachet } \\
\text { Administration: sachets } \\
\text { Frequency: } 2 \text { times/day } \\
\text { Control group: nothing } \\
\text { Treatment period: started } \\
\text { on day } 2 \text { of admission and } \\
\text { continued during the } \\
\text { entire period of } \\
\text { hospitalisation }\end{array}$ & $\begin{array}{l}\text { Mean body surface } \\
\text { area grafted and } \\
\text { mean graft loss }\end{array}$ & $\begin{array}{l}\text { 1. Mean body surface area grafted } \\
\text { for each patient was higher in } \\
\text { the probiotic group (probiotics: } \\
10.81 \% \text { vs. control: } 9.75 \% \text {, } \\
p=0.0917 \text { ). } \\
\text { Mean graft loss was higher in } \\
\text { the control group (probiotics: } \\
20.14 \% \text { vs. control: } 29.26 \%, \\
p=0.0093 \text { ). }\end{array}$ \\
\hline $\begin{array}{l}\text { Twetman et al. } 2018 \\
\text { (Denmark) [30] }\end{array}$ & $\begin{array}{l}\text { To investigate the impact } \\
\text { of topical and systemic } \\
\text { applications of probiotic } \\
\text { lactobacilli on the healing } \\
\text { of standardised wounds in } \\
\text { adult patients }\end{array}$ & $\begin{array}{c}\text { Randomised, } \\
\text { placebo-controlled, } \\
\text { double-blind, cross-over } \\
\text { design }\end{array}$ & $\begin{array}{l}\text { Total: } 10 \text { ( } 2 \text { males) Age: } \\
\text { Mean age: } 29.5 \text { years } \\
\text { (range 21-66 years) }\end{array}$ & Oral mucosa & $\begin{array}{l}\text { Probiotics: Lactobacillus } \\
\text { reuteri (DSM } 17938 \text { and } \\
\text { ATCC PTA 5289) } \\
\text { Dosage: at least } 5 \times 10^{8} \\
\text { live bacteria of each } \\
\text { strain/lozenge } \\
\text { Administration: lozenges } \\
\text { Frequency: } 2 \text { times/day } \\
\text { Placebo group: lozenges } \\
\text { had an identical } \\
\text { composition, shape, and } \\
\text { taste, but without active } \\
\text { bacteria } \\
\text { Treatment period: } 8 \text { days } \\
\text { before the biopsy and a } \\
\text { further } 8 \text { days after }\end{array}$ & $\begin{array}{l}\text { Four-level clinical } \\
\text { score }\end{array}$ & $\begin{array}{l}\text { No statistically significant differences } \\
\text { in the oral wound healing pattern } \\
\text { between test and placebo. * }\end{array}$ \\
\hline
\end{tabular}


Table 1. Cont.

\begin{tabular}{|c|c|c|c|c|c|c|c|}
\hline Study (Country) & Aim of the Study & $\begin{array}{c}\text { Study } \\
\text { Design }\end{array}$ & $\begin{array}{c}\text { Subjects/ } \\
\text { Patients }\end{array}$ & Type of Wounds & Intervention Protocol & $\begin{array}{c}\text { Healing } \\
\text { Assessments }\end{array}$ & Outcome of Interest \\
\hline $\begin{array}{l}\text { Wälivaara et al. } 2019 \\
\text { (Sweden) [25] }\end{array}$ & $\begin{array}{l}\text { To investigate the effect of } \\
\text { oral probiotic therapy on } \\
\text { oral wound healing and to } \\
\text { assess local bacterial } \\
\text { growth and the } \\
\text { postoperative } \\
\text { concentrations of oxytocin } \\
\text { in saliva }\end{array}$ & $\begin{array}{l}\text { Randomised } \\
\text { placebo-controlled trial }\end{array}$ & $\begin{array}{l}\text { Total: } 64 \text { ( } 31 \text { males) Group } \\
1 \text { (probiotic): } 30 \\
\text { Group } 2 \text { (placebo): } 31 \text { Age: } \\
\text { Mean age: } 29.9 \text { years } \\
\text { (range 18-34) }\end{array}$ & Oral mucosa & $\begin{array}{l}\text { Probiotics: Lactobacillus } \\
\text { reuteri (DSM 17938 and } \\
\text { ATCC PTA } 5289 \text { ) } \\
\text { Dosage: at least } 2 \times 10^{8} \\
\text { live bacteria } \\
\text { Administration: lozenges } \\
\text { Frequency: } 3 \text { times/day } \\
\text { (one in the morning, one at } \\
\text { lunchtime, and one in the } \\
\text { evening) } \\
\text { Placebo group: lozenges } \\
\text { had an identical colour, } \\
\text { shape, and taste, but } \\
\text { without active bacteria } \\
\text { Treatment period: } 2 \text { weeks }\end{array}$ & $\begin{array}{l}\text { Clinical healing } \\
\text { index scores }\end{array}$ & $\begin{array}{l}\text { No differences between the groups in } \\
\text { the distribution of the healing scores.* }\end{array}$ \\
\hline
\end{tabular}

CFU: colony-forming units, WLOS: was defined as the point in recovery when the wounds were $95 \%$ closed, * does not report a $p$-value 
Regarding the type of wounds, the studies included burn wounds [24,26,28], surgical wounds [27], diabetic foot ulcers [29], and oral mucosal wounds [25,30]. The intervention protocols were Lactobacillus reuteri (DSM 17938 and ATCC PTA 5289) [25,30], L. fermentum and L. delbruekii [26], L. rhamnosus GG (ATCC 53103) [27], L. rhamnosus GG [28], L. acidophilus, L. casei, L. fermentum and Bifidobacterium bifidum [29], L. acidophilus LA-5, Bifidobacterium BB-12, Streptococcus thermophilus STY-31, and L. delbrueckii ssp. bulgaricus LBY-27 [24]. The prescription of probiotics in these studies varied with respect to the doses and administration forms, such as sachets [24,26], drops [27], nasoduodenal feeding tube [28], capsules [29], and lozenges [25,30]. The frequency of probiotic therapy in the studies was 1-3 times/day, and the treatment period varied according to the duration of antibiotic use [27], length of hospitalisation [24], the time required to achieve 95\% wound healing [28], or the defined research protocol $[25,26,29,30]$.

The healing assessments were conducted locally based either on the need for grafting [26], number of dressing changes per day and post-operative wound complications [27], wound duration and operative days for excision and graft [28], ulcer mean surface area and volume [29], mean body surface area grafted and mean graft loss [24], and healing clinical scores $[25,30]$.

\subsection{Risk of Bias within Studies}

Three of the seven studies included in this review $[26,29,30]$ had a low risk of bias. Six parameters of the critical appraisal checklist were met in all randomised controlled clinical trials [25-30] (Figure 2). The only non-randomised clinical trial [24] that was included was found to meet seven of the nine parameters assessed using the instrument (Table S3).

\subsection{Results of Individual Studies}

El-Ghazely et al. found that paediatric patients undergoing probiotic therapy had a significantly lower need for grafting; when grafting was not performed, there was a significant decrease in the time required for complete healing of the wound [26]. Tahir et al. found that adult patients receiving probiotic therapy had a larger mean grafted body surface area than those in the control group, but not significantly so. In the same study, the mean graft loss was significantly higher in the control group [24]. In contrast, Mayes et al. did not report differences in the number of operative days for excision and grafting procedures, or the time needed for healing in paediatric patients with or without probiotic therapy [28].

Positive results were also observed for probiotic treatment of surgical wounds [27] and diabetic foot ulcers [29]. Esposito et al. found that the daily frequency of dressing changes was significantly lower in paediatric patients on probiotic therapy (1.7 times/day) than in those in the antibiotics group (3.3 times/day) and in the antibiotics and placebo group (2.8 times/day). In parallel, the incidence of post-operative wound complications was significantly higher in the groups without probiotic therapy [27]. Mohseni et al. observed a significant improvement in the ulcer healing parameters with respect to its length, width, and depth in adults on probiotic therapy [29]. Three studies, two among adults [25,30] and one among paediatric patients [28], did not find improvement in wound healing with probiotic therapy.

It was not possible to conduct a meta-analysis due to the different outcomes assessed across the studies, mainly because of the wide variation in the methods used to evaluate the effects of probiotic therapy, population heterogeneity, type of wounds, and intervention protocols of each study. 


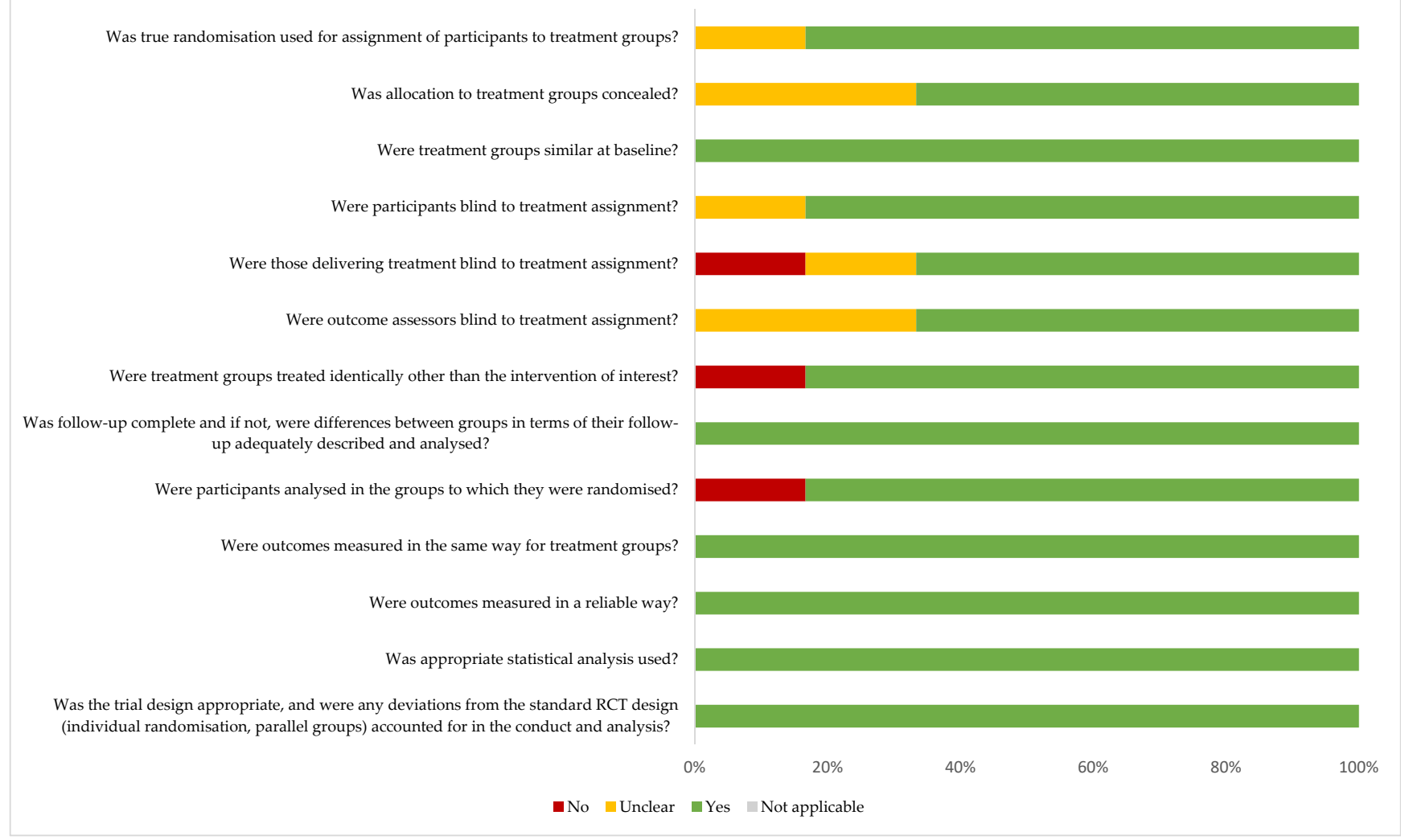

Figure 2. Risk of bias in the included studies (The Joanna Briggs Institute Critical Appraisal Checklist for Randomised Controlled Trials).

\section{Discussion}

The results of this systematic review indicate that there is no consensus on, or highlevel evidence for, the effectiveness of probiotic therapy for wound healing owing to the differences in the type of wounds, target population, and criteria for assessing the effect between studies. Nevertheless, it is important to highlight that none of the studies reported adverse effects due to probiotic therapy or a marked increase in the healing time of wounds.

The first studies that dealt with probiotics in dermatology, specifically in atopic dermatitis, were from the first decade of the 2000s. It is therefore an emerging theme that has mainly been researched by means of in vitro and animal studies [31-33].

The health-promoting properties of probiotics are suggested to be strain-dependent. The identity and characteristics of the strain are of paramount importance [34], as probiotics may regulate cytokine production and activate antimicrobial immune responses. For instance, some probiotics may induce interleukin (IL)-12, which increases the secretion of interferon (IFN)- $\gamma$ and activates natural killer (NK) cells. However, they also stimulate the increase of IL-10 that induces antibody production and downregulates the inflammatory response, balancing it and contributing to healing [35]. It is noteworthy that these effects seem to be strain-specific, at least to some degree [36]. Lactobacillus strains are capable of inducing pro-inflammatory cytokines such as IL-12 and IFN- $\gamma$ in addition to anti-inflammatory cytokines such as IL-10 [35], whereas Bifidobacterium strains are generally better inducers of IL-10 than Lactobacillus strains $[37,38]$. However, an in vitro study conducted by Dong et al. found little evidence for strain-specific effects of six probiotics on NK cell activity and NK cell or T cell activation. Cytokine production is differentially altered by the probiotic strains of distinct species. Thus, the in vivo biological importance of these strain-specific effects still needs to be elucidated [39].

The studies included in this review that found positive outcomes mainly evaluated the need for grafting, loss of graft, ulcer size, number of dressings per day, and incidence of 
post-operative wound complications. Meanwhile, when the wounds were assessed using clinical scores, probiotic treatment did not show any significant effect. Skin grafting is the preferred treatment for deep dermal burns, wherein necrotic and inflamed tissues are removed, and faster physiological wound closure is promoted [40]. El-Ghazely et al. found a decrease in the need for grafting in patients treated with probiotics [26]. However, because of the scarcity of studies examining the use of oral probiotics associated with grafting procedures, this effect needs further confirmation. It has already been demonstrated that the strain L. fermentum lowers keratinocyte viability and re-epithelialisation in in vitro studies [19,41]. Considering that infection is the second most common cause of graft loss [42], it is possible that therapeutic microorganisms may improve systemic immune functioning [43], favouring the healing process.

The studies included in this review did not elucidate the mechanisms of action of probiotics in the improvement of wound healing. Although the role of the intestinal microbiome in human health and disease is widely known, the role of the skin microbiome in wound healing is less well-defined [44]. Poutahidis et al. identified that oral therapy with probiotics leads to rapid deposition of collagen that is essential for proper wound healing [45]. Yu et al. assessed whether clinical data support the utility of oral and topical probiotics for certain dermatological conditions including chronic wounds. They reported that probiotics can promote the healing process by modulating the inflammatory response and limiting the colonisation of pathogens [16]. A literature review conducted by Lukic et al. identified three possible routes of action of oral probiotic therapy in wound healing. The first pathway is through the central nervous system, where probiotics produce neuroactive molecules and/or modulate the secretory activity of enteroendocrine cells in the intestinal mucosa, leading to the release of neuromodulators with the potential to improve tissue regeneration. The second route is through immunomodulation, in which intestinal probiotics can stimulate the recruitment of lymphocytes to the injured tissue, contributing to the activation of innate and adaptive immune responses. The third route is through the improved absorption of essential nutrients, especially vitamins, minerals, and enzyme cofactors involved in tissue repair to heal skin wounds [8].

Wälivaara et al. [25] and Twetman et al. [30] used the lowest doses of probiotics, in contrast to other studies [24,26-29], and found no beneficial effects on wound healing. In addition, Wälivaara et al. [25] evaluated the effect of probiotic treatment over a longer period, and Twetman et al. [30] applied a non-validated instrument to assess wound healing. The heterogeneity of these results can also be attributed to differences in the skin microbiome between various regions of the body, such as between drier or more humid areas, or areas with a greater number of sebaceous glands [44]. Beyond this, the studies included in this review did not address the nutritional aspect and gastrointestinal microbiota of individual subjects, although it is known that these factors can influence the wound healing process, as they can affect the immune system. Both malnutrition and dysbiosis are factors that can negatively contribute to proper wound healing [3,4,46]. Therefore, it is important that future studies include the assessment of these factors in wound healing.

Regarding the age range of the patients, previous studies $[1,47,48]$ showed that increasing age is associated with a slight delay in healing, rather than a real loss in its quality. However, it is difficult to identify whether the delay in healing is due to age, or rather diseases that are commonly associated with advancing age. Although the studies included in this review did not evaluate the age of the participants in relation to healing, it is noteworthy that Mohseni et al. found a significant improvement in ulcer healing after probiotic therapy in participants aged 40-85 years [29].

In certain diseases such as epidermolysis bullosa, or in conditions such as diabetic ulcers and extensive burns, in which the healing processes are constant or time-consuming, the need for an effective healing treatment becomes paramount in order to guarantee a better quality of life. Spanos et al. [49] evaluated the impact of the treatment of ulcers and the quality of life of patients with diabetes $(n=103)$ based on the following items: 
leisure, physical health, dependence/daily life, negative emotions and concerns about ulcers, and discomfort regarding ulcer care. After treatment, the quality of life significantly improved for all assessment items when compared with before treatment. This highlights the importance of effective healing and its relationship to quality of life as an underresearched topic. Therefore, further studies concerning the use of probiotic therapy should be encouraged, since all efforts to favour the healing process can benefit global health and quality of life, which are often compromised in patients with inflammatory skin conditions.

The studies included in this review did not report adverse effects on the clinical risk and safety of oral/enteral probiotic therapy. However, a previous report of more than 600 studies examining the safety of probiotics on microorganisms from six genera, found that, despite the actual probiotic clinical trials showing no evidence of increased risk, the present literature is not well-equipped to answer questions about probiotic safety based on intervention studies with assurance [50].

The strengths of this review are the originality of the study, as well as the methods and expert search strategies used. However, the main limitation is the low certainty of the evidence, due to the small number of studies evaluating the outcomes of interest. This may be because the use of probiotics to treat several types of wounds is an emerging topic of interest. There is also notable variation in the scales used to evaluate the effects of probiotics on wound healing, which made it impossible for us to conduct a meta-analysis.

\section{Conclusions}

We found few studies that have investigated the relationship between probiotic therapy and wound healing. Furthermore, among the studies included in this review, we observed a wide variety of probiotic strains used, types of wounds, and target populations, which prevented us from drawing clear conclusions regarding the effectiveness of probiotic therapy for wound healing. However, we found no marked increase in wound healing time or adverse effects in any of the included studies, highlighting this as a promising field for further clinical investigation.

Supplementary Materials: The following are available online at https:/ /www.mdpi.com/article/10 .3390/nu14010111/s1, Table S1: Database search strategy; Table S2: Full-text articles excluded with reasons $(n=23)$; and Table S3: Risk of bias in the included studies-Critical Appraisal Checklist for Randomised Controlled Trials and for Quasi-Experimental Studies (non-randomised experimental studies).

Author Contributions: Conceptualization, C.T., A.P.Z. and E.D.; methodology, C.T., A.P.Z., V.G., P.B., K.d.C. and E.D.; formal analysis, C.T. and A.P.Z.; investigation, C.T. and A.P.Z.; data curation, C.T. and A.P.Z.; writing-original draft preparation, C.T. and A.P.Z.; writing-review and editing, C.T., A.P.Z., V.G., P.B., K.d.C. and E.D.; visualization, C.T., A.P.Z., V.G., P.B., K.d.C. and E.D.; supervision, V.G., P.B., K.d.C. and E.D.; project administration, C.T. and A.P.Z. All authors have read and agreed to the published version of the manuscript.

Funding: This research received no external funding.

Institutional Review Board Statement: Not applicable.

Informed Consent Statement: Not applicable.

Acknowledgments: The authors acknowledge Coordenação de Aperfeiçoamento de Pessoal de Nível Superior (CAPES) - Brasil for the PhD scholarship (C.T.), and the University of Brasilia's support. We appreciate the review and suggestions in the PRESS checklist by Nathalia Marcolini Pelucio Pizato and revisions of the manuscript by Maísa Miranda Araújo, Carolina de Oliveira Vogado, and Marcela Moraes Mendes.

Conflicts of Interest: The authors declare no conflict of interest. 


\section{References}

1. Broughton, G.; Janis, J.E.; Attinger, C.E. Wound healing: An overview. Plast. Reconstr. Surg. 2006, 117, 1e-S-32e-S. [CrossRef] [PubMed]

2. Campos, A.C.L.; Borges-Branco, A.; Groth, A.K. Cicatrização de feridas. ABCD Arq. Bras. Cir. Dig. 2007, 20, 51-58. [CrossRef]

3. Renner, R.; Garibaldi, M.; Benson, S.; Ronicke, M.; Erfurt-Berge, C. Nutrition status in patients with wounds: A cross-sectional analysis of 50 patients with chronic leg ulcers or acute wounds. Eur. J. Dermatol. 2019, 29, 619-626. [CrossRef] [PubMed]

4. Quain, A.M.; Khardori, N.M. Nutrition in wound care management: A comprehensive overview. Wounds 2015, 27, 327-335.

5. Patel, S.; Srivastava, S.; Singh, M.R.; Singh, D. Mechanistic insight into diabetic wounds: Pathogenesis, molecular targets, and treatment strategies to pace wound healing. Biomed. Pharmacother. 2019, 112, 108615. [CrossRef] [PubMed]

6. Mandelbaum, S.H.; Di Santis, É.P.; Mandelbaum, M.H.S. Cicatrização: Conceitos atuais e recursos auxiliaries-Parte I. An. Bras. Dermatol. 2003, 78, 393-408. [CrossRef]

7. Hill, C.; Guarner, F.; Reid, G.; Gibson, G.R.; Merenstein, D.J.; Pot, B.; Morelli, L.; Canani, R.B.; Flint, H.J.; Salminen, S.; et al. The International Scientific Association for Probiotics and Prebiotics consensus statement on the scope and appropriate use of the term probiotic. Nat. Rev. Gastroenterol. Hepatol. 2014, 11, 506-514. [CrossRef]

8. Lukic, J.; Chen, V.; Strahinic, I.; Begovic, J.; Lev-Tov, H.; Davis, S.C.; Tomic-Canic, M.; Pastar, I. Probiotics or pro-healers: The role of beneficial bacteria in tissue repair. Wound Repair Regen. 2017, 25, 912-922. [CrossRef] [PubMed]

9. Tsiouris, C.G.; Tsiouri, M.G. Human microflora, probiotics, and wound healing. Wound Med. 2017, 19, 33-38. [CrossRef]

10. Lenoir-Wijnkoop, I.; Sanders, M.E.; Cabana, M.D.; Caglar, E.; Corthier, G.; Rayes, N.; Sherman, P.M.; Timmerman, H.M.; Vaneechoutte, M.; Van Loo, J.; et al. Probiotic and prebiotic influence beyond the intestinal tract. Nutr. Rev. 2007, 65, 469-489. [CrossRef] [PubMed]

11. Quick, M. Cochrane commentary: Probiotics for prevention of acute upper respiratory infection. Explore 2015, 11, 418-420. [CrossRef] [PubMed]

12. Álvarez-Arraño, V.; Martín-Peláez, S. Effects of probiotics and synbiotics on weight loss in subjects with overweight or obesity: A systematic review. Nutrients 2021, 13, 3627. [CrossRef] [PubMed]

13. Hojsak, I.; Snovak, N.; Abdović, S.; Szajewska, H.; Mišak, Z.; Kolaček, S. Lactobacillus GG in the prevention of gastrointestinal and respiratory tract infections in children who attend day care centers: A randomized, double-blind, placebo-controlled trial. Clin. Nutr. 2010, 29, 312-316. [CrossRef] [PubMed]

14. Wang, Y.; Li, X.; Ge, T.; Xiao, Y.; Liao, Y.; Cui, Y.; Zhang, Y.; Ho, W.; Yu, G.; Zhang, T. Probiotics for prevention and treatment of respiratory tract infections in children: A systematic review and meta-analysis of randomized controlled trials. Medicine 2016, 95, e4509. [CrossRef] [PubMed]

15. Bustamante, M.; Oomah, B.D.; Oliveira, W.P.; Burgos-Díaz, C.; Rubilar, M.; Shene, C. Probiotics and prebiotics potential for the care of skin, female urogenital tract, and respiratory tract. Folia Microbiol. 2020, 65, 245-264. [CrossRef]

16. Yu, Y.; Dunaway, S.; Champer, J.; Kim, J.; Alikhan, A. Changing our microbiome: Probiotics in dermatology. Br. J. Dermatol. 2020, 182, 39-46. [CrossRef] [PubMed]

17. Valdéz, J.C.; Peral, M.C.; Rachid, M.; Santana, M.; Perdigón, G. Interference of Lactobacillus plantarum with Pseudomonas aeruginosa in vitro and in infected burns: The potential use of probiotics in wound treatment. Clin. Microbiol. Infect. 2005, 11, 472-479. [CrossRef] [PubMed]

18. Han, N.; Jia, L.; Su, Y.; Du, J.; Guo, L.; Luo, Z.; Liu, Y. Lactobacillus reuteri extracts promoted wound healing via PI3K/AKT/ $\beta$ catenin/TGF $\beta 1$ pathway. Stem Cell Res. Ther. 2019, 10, 243. [CrossRef] [PubMed]

19. Mohammedsaeed, W.; Cruickshank, S.; McBain, A.J.; O'Neill, C.A. Lactobacillus rhamnosus GG lysate increases reepithelialization of keratinocyte scratch assays by promoting migration. Sci. Rep. 2015, 5, 16147. [CrossRef]

20. Liberati, A.; Altman, D.G.; Tetzlaff, J.; Mulrow, C.; Gøtzsche, P.C.; Ioannidis, J.P.A.; Clarke, M.; Devereaux, P.J.; Kleijnen, J.; Moher, D. The PRISMA statement for reporting systematic reviews and meta-analyses of studies that evaluate health care interventions: Explanation and elaboration. PLoS Med. 2009, 6, e1000100. [CrossRef]

21. McGowan, J.; Sampson, M.; Salzwedel, D.M.; Cogo, E.; Foerster, V.; Lefebvre, C. PRESS Peer Review of Electronic Search Strategies: 2015 guideline statement. J. Clin. Epidemiol. 2016, 75, 40-46. [CrossRef]

22. Ouzzani, M.; Hammady, H.; Fedorowicz, Z.; Elmagarmid, A. Rayyan-A web and mobile app for systematic reviews. Syst. Rev. 2016, 5, 210. [CrossRef]

23. Tufanaru, C.; Munn, Z.; Aromataris, E.; Campbell, J.; Hopp, L. Chapter 3: Systematic reviews of effectiveness. In Joanna Briggs Institute Reviewer's Manual; Aromataris, E., Munn, Z., Eds.; The Joanna Briggs Institute: Adelaide, Australia, 2017.

24. Tahir, S.M.; Makhdoom, A.; Awan, S.; Ali, S. Role of probiotics in the management of burns patients. World J. Med. Sci. 2014, 11, 417-421. [CrossRef]

25. Wälivaara, D.Å.; Sjögren, I.; Gerasimcik, N.; Yucel-Lindberg, T.; Twetman, S.; Abrahamsson, P. Effects of Lactobacillus reutericontaining lozenges on healing after surgical removal of mandibular third molars: A randomised controlled trial. Benef. Microbes 2019, 10, 653-659. [CrossRef]

26. El-Ghazely, M.H.; Mahmoud, W.H.; Atia, M.A.; Eldip, E.M. Effect of probiotic administration in the therapy of pediatric thermal burn. Ann. Burn. Fire Disasters 2016, 29, 268-272. 
27. Esposito, C.; Roberti, A.; Turrà, F.; Cerulo, M.; Severino, G.; Settimi, A.; Escolino, M. Frequency of antibiotic-associated diarrhea and related complications in pediatric patients who underwent hypospadias repair: A comparative study using probiotics vs placebo. Probiotics Antimicrob. Proteins 2018, 10, 323-328. [CrossRef]

28. Mayes, T.; Gottschlich, M.M.; James, L.E.; Allgeier, C.; Weitz, J.; Kagan, R.J. Clinical safety and efficacy of probiotic administration following burn injury. J. Burn. Care Res. 2015, 36, 92-99. [CrossRef] [PubMed]

29. Mohseni, S.; Bayani, M.; Bahmani, F.; Tajabadi-Ebrahimi, M.; Bayani, M.A.; Jafari, P.; Asemi, Z. The beneficial effects of probiotic administration on wound healing and metabolic status in patients with diabetic foot ulcer: A randomized, double-blind, placebo-controlled trial. Diabetes Metab. Res. Rev. 2018, 34, e2970. [CrossRef] [PubMed]

30. Twetman, S.; Pedersen, A.M.L.; Yucel-Lindberg, T. Probiotic supplements containing Lactobacillus reuteri does not affect the levels of matrix metalloproteinases and interferons in oral wound healing. BMC Res. Notes 2018, 11, 759. [CrossRef]

31. McClean, K. Probiotics help reduce severity of atopic dermatitis. J. Pediatr. 2006, 148, 143-144. [CrossRef] [PubMed]

32. Hsu, C.J.; Wang, L.F. Emerging treatment of atopic dermatitis. Clin. Rev. Allergy Immunol. 2007, 33, 199-203. [CrossRef]

33. Viljanen, M.; Savilahti, E.; Haahtela, T.; Juntunen-Backman, K.; Korpela, R.; Poussa, T.; Tuure, T.; Kuitunen, M. Probiotics in the treatment of atopic eczema/dermatitis syndrome in infants: A double-blind placebo-controlled trial. Allergy 2005, 60, 494-500. [CrossRef]

34. Salminen, S.; Collado, M.C.; Isolauri, E.; Gueimonde, M. Microbial-host interactions: Selecting the right probiotics and prebiotics for infants. In Microbial Host-Interaction: Tolerance versus Allergy; Brandtzaeg, P., Isoulari, E., Prescott, S.L., Eds.; Karger: Basel, Switzerland, 2009; pp. 201-217.

35. Hessle, C.; Andersson, B.; Wold, A.E. Gram-positive bacteria are potent inducers of monocytic interleukin-12 (IL-12) while gram-negative bacteria preferentially stimulate IL-10 production. Infect. Immun. 2000, 68, 3581-3586. [CrossRef] [PubMed]

36. Borchers, A.T.; Selmi, C.; Meyers, F.J.; Keen, C.L.; Gershwin, M.E. Probiotics, and immunity. J. Gastroenterol. $2009,44,26-46$. [CrossRef] [PubMed]

37. Kekkonen, R.A.; Kajasto, E.; Miettinen, M.; Veckman, V.; Korpela, R.; Julkunen, I. Probiotic Leuconostoc mesenteroides ssp. cremoris and Streptococcus thermophilus induce IL-12 and IFN- $\gamma$ production. World J. Gastroenterol. 2008, 14, 1192-1203. [CrossRef] [PubMed]

38. Hart, A.L.; Lammers, K.; Brigidi, P.; Vitali, B.; Rizzello, F.; Gionchetti, P.; Campieri, M.; Kamm, M.A.; Knight, S.C.; Stagg, A.J. Modulation of human dendritic cell phenotype and function by probiotic bacteria. Gut 2004, 53, 1602-1609. [CrossRef]

39. Dong, H.; Rowland, I.; Yaqoob, P. Comparative effects of six probiotic strains on immune function in vitro. Br. J. Nutr. 2012, 108, 459-470. [CrossRef] [PubMed]

40. Orgill, D.P. Excision and skin grafting of thermal burns. N. Engl. J. Med. 2009, 360, 893-901. [CrossRef]

41. Sultana, R.; McBain, A.J.; O'Neill, C.A. Strain-dependent augmentation of tight-junction barrier function in human primary epidermal keratinocytes by Lactobacillus and Bifidobacterium lysates. Appl. Environ. Microbiol. 2013, 79, 4887-4894. [CrossRef] [PubMed]

42. McGregor, A.; McGregor, I. Free skin grafts. In Fundamental Techniques of Plastic Surgery and Their Surgical Applications; McGregor, A., McGregor, I., Eds.; Churchill Livingstone: Philadelphia, PA, USA, 2000; pp. 35-59.

43. Wolvers, D.; Antoine, J.-M.; Myllyluoma, E.; Schrezenmeir, J.; Szajewska, H.; Rijkers, G.T. Guidance for substantiating the evidence for beneficial effects of probiotics: Prevention and management of infections by probiotics. J. Nutr. 2010, 140, 698S-712S. [CrossRef] [PubMed]

44. Johnson, T.R.; Gómez, B.; McIntyre, M.; Dubick, M.; Christy, R.; Nicholson, S.; Burmeister, D. The cutaneous microbiome and wounds: New molecular targets to promote wound healing. Int. J. Mol. Sci. 2018, 19, 2699. [CrossRef] [PubMed]

45. Poutahidis, T.; Kearney, S.M.; Levkovich, T.; Qi, P.; Varian, B.J.; Lakritz, J.R.; Ibrahim, Y.M.; Chatzigiagkos, A.; Alm, E.J.; Erdman, S.E. Microbial symbionts accelerate wound healing via the neuropeptide hormone oxytocin. PLoS ONE 2013, 8, e78898. [CrossRef]

46. Noverr, M.C.; Huffnagle, G.B. Does the microbiota regulate immune responses outside the gut? Trends Microbiol. 2004, 12, 562-568. [CrossRef] [PubMed]

47. Thomas, D.R. Age-related changes in wound healing. Drugs Aging 2001, 18, 607-620. [CrossRef]

48. Gosain, A.; DiPietro, L.A. Aging and wound healing. World J. Surg. 2004, 28, 321-326. [CrossRef] [PubMed]

49. Spanos, K.; Saleptsis, V.; Athanasoulas, A.; Karathanos, C.; Bargiota, A.; Chan, P.; Giannoukas, A.D. Factors associated with ulcer healing and quality of life in patients with diabetic foot ulcer. Angiology 2017, 68, 242-250. [CrossRef] [PubMed]

50. Hempel, S.; Newberry, S.; Ruelaz, A.; Wang, Z.; Miles, J.N.V.; Suttorp, M.J.; Johnsen, B.; Shanman, R.; Slusser, W.; Fu, N.; et al. Safety of probiotics used to reduce risk and prevent or treat disease. Evid. Rep. Technol. Assess. 2011, 200, 1-645. 